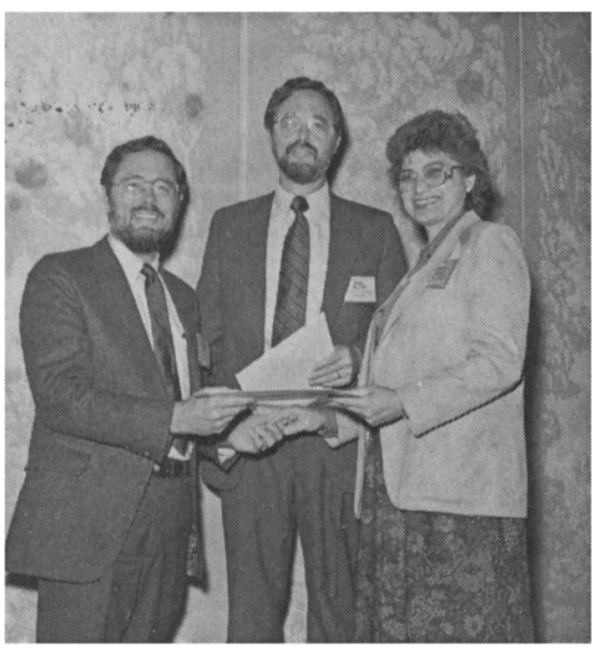

Merle and Earl Black receive the Ralph \}. Bunche Award from Rita Mae Kelly.

1987 in the field of American government, for Dynamics of U.S. Senate Elections, submitted by the University of California, Berkeley; dissertation chair, Raymond $E$. Wolfinger.

Peter Berkowitz, Deerfield, lllinois, the Leo Strauss Award, for the best doctoral dissertation in the field of political philosophy, for The Foundations of Nietzsche's Political Philosophy, submitted by Yale University; dissertation chair, Joseph Hamburger.

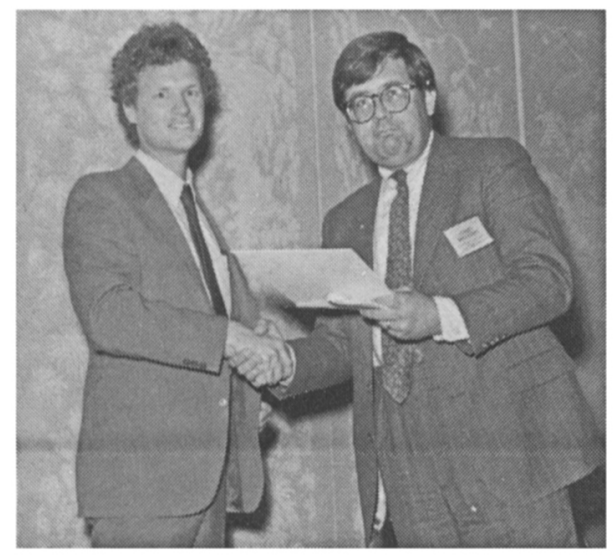

David Magleby presents the E. E. Schattschneider Dissertation Award to Mark Westlye.

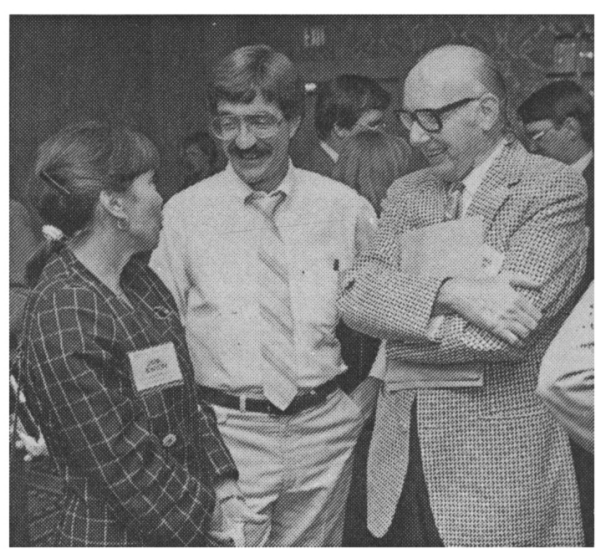

Jane Jenson, Morris Fiorina and William Riker help celebrate the 25th anniversary of the University of Rochester's Ph.D. program.

Chris C. Demchak, U.S. Military Academy, West Point, the Leonard D. White Award, for the best doctoral dissertation in the field of public administration, including broadly related problems of policy formation, for War, Technological Complexity, and the U.S. Army, submitted by the University of California, Berkeley; dissertation chair, Todd R. LaPorte.

Neither the William Anderson Award for the best doctoral dissertation in the field of intergovernmental relations, nor the Harold D. Lasswell Award for the best doctoral dissertation in the field of policy studies were awarded in 1988.

Editor's Note: For the full text of citations, see the Gazette in this issue of PS.

\section{Nelson and Peltason Are Honored at Washington Annual Meeting}

William E. Nelson of Ohio State Univer. sity and Jack W. Peltason, Chancellor of the University of California-Irvine, were honored by the APSA Committee on the Status of Blacks in the Profession at the annual meeting. Plaques were presented 
to Nelson and Peltason at the Committee's annual reception.

Nelson and Peltason were recognized for their contributions to the political science discipline and their efforts to improve the status of black Americans. The committee began its awards program nine years ago to commend those who have advanced the interests of black political scientists and have distinguished themselves as scholars, teachers, or activists in civic affairs.

Michael Preston of the University of Southern California, chair of the Committee on the Status of Blacks, presided over the awards ceremony. Other members of the committee include: Woodrow Jones, Jr., San Diego State University; Roger Oden, Governors State University; Gary Orfield, University of Chicago; and Ernest Wilson, University of Michigan.

\section{APSA Annual Meeting Placement Service}

The Annual Meeting Placement Service in Washington could barely contain the pressure of job seekers and prospective employers. The 1988 Placement Service recorded an increase in the number of employers using the service, the number of job applicants, and most significantly, the number of positions available.

Table 1. Annual Meeting Placement Services, 1986, 1987, and 1988

\begin{tabular}{lll}
\hline 1986 & 1987 & 1988 \\
Washington & Chicago & Washington \\
\hline
\end{tabular}

127 Employers 143 Employers 161 Employers 487 Applicants 423 Applicants 545 Applicants 213 Positions 227 Positions 252 Positions 6 Various* 9 Various* 4 Various*

"Various refers to listings of more than one position at a single institution.

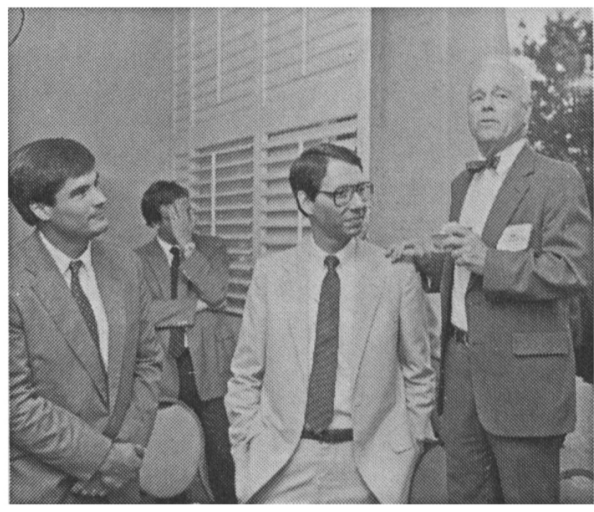

Friends and alumni of the University of Virginia's Department of Government and Foreign Affairs honor the retirement of Inis L. Claude.

\section{Recent LSS Activities Reviewed and Plans for 1988-89 Set}

At the Annual Business Meeting of the Legislative Studies Section of the American Political Science Association in Washington, DC, on September 2, 1988, Alan Abramovitz of Emory University was elected as Program Chairman of the Section for 1988-89. In this capacity, he will

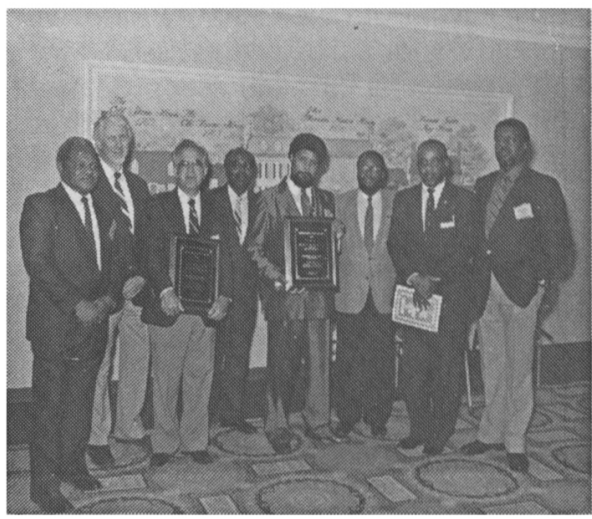

Committee on the Status of Blacks in the Profession honors Peltason and Nelson: I. to r., Michael Preston, Robert Salisbury, Jack W. Peltason, Lucius Barker, William E. Nelson, A. L. Stokes, Maurice Woodard and Mitchell Rice. 